\title{
Evaluation of Oral Mucosal Lesions in 598 Referred Iranian Patients
}

\author{
Jahanfar Jahanbani ${ }^{1}$, Leiv Sandvik ${ }^{2,3}$, Torstein Lyberg ${ }^{3}$ and Eva Ahlfors ${ }^{3,4, *}$
}

\author{
${ }^{I}$ Department of Oral Pathology, School of Dentistry, Islamic Azad University of Tehran, Iran; ${ }^{2}$ Institute of Oral Biology, \\ School of Dentistry, University of Oslo, Norway; ${ }^{3}$ Center for Clinical Research, Ullevaal University Hospital, Oslo, \\ Norway and ${ }^{4}$ Present address: Department of Oral Pathology, Institute of Dentistry, Faculty of Medicine, University of \\ Turku, Finland
}

\begin{abstract}
The mucosal membrane of the oral cavity displays at times classical developmental lesions considered to be variations of normal structures rather than having disease characteristics. Of these lesions leukoedema, Fordyce granules, geographic-, fissured- and hairy tongue, median rhomboid glossitis and lingual varices were studied in 598 patients referred to the School of Dentistry, Tehran, Iran. The prevalence was studied in relation to age, gender, occupation, education, smoking habits, general health, addictions and or drug therapies. Oral developmental lesions were seen in 295 patients $(49.3 \%)$. Only Fordyce granules $(27,9 \%)$, fissured tongue $(12,9 \%)$, leukoedema $(12,5 \%)$ and hairy tongue $(8,9 \%)$ had enough cases for statistical analysis. Three of these lesions increased with age but not fissured tongue. All were more common in men. After adjusting for age, the parameters education, occupation and complaints upon referral had little influence on the prevalence of the lesions. Fewer Fordyce granules were seen in oral mucosa of smoking men. Leukoedema and hairy tongue were significantly associated with smoking, leukoedema with diabetes mellitus. We conclude that there was a highly significant association between these oral lesions and age, gender and smoking. Few significant associations were found between oral lesions and general diseases.
\end{abstract}

Key Words: Oral lesions, statistics, general diseases.

\section{INTRODUCTION}

Traditionally, the mucosal membrane of the oral cavity has been looked upon as mirroring the general health. The tongue lesions fissured-, geographic- and hairy tongue, median rhomboid glossitis and lingual varices and the oral lesions Fordyce granules and leukoedema are classically considered to be developmental oral lesions, normal conditions rather than having virtual disease characteristics [1]. These lesions may be present at birth or become evident later in life. They may be discovered during routine dental examinations and vary depending on age, gender and/or race [2-5]. Some systemic diseases presents with local symptoms and/or lesions in the oral mucosa, mainly in the tongue. Moreover, papillae atrophy in fissured tongue is considered to be transmitted dominantly with incomplete penetrance and is preceded by geographic tongue [4]. Tongue fissuring with normal-appearing filiform papillae was neither familial nor associated with geographic tongue [4]. The histological picture seen in geographic tongue has a psoriasiform pattern [6] and some authors regard it as an oral mucosa form of psoriasis [7]. Tongue lesions in general are more frequent in patients with diabetes mellitus, hematological disorders and gastrointestinal diseases [8]. Atrophy of the papillae of the tongue is seen in iron deficiency anemia [9]. Although harmless, some authors have found a distinct relationship between these developmental conditions and environmental influences

*Address correspondence to this author at the Department of Oral Pathology, Institute of Dentistry, Faculty of Medicine, University of Turku, FI20520 Turku, Finland; Tel: +35823338211; Fax: +35823338399;

E-mail: evaahl@utu.fi such as the effect of smoking on the prevalence of leukoedema $[5,10-13]$. The aim of this study was to investigate the prevalence of these lesions in relation to gender and age, smoking habits, occupation, education, and the reasons for referral as well as their relation to general diseases in a population referred to a dental school in Tehran, Iran.

\section{MATERIALS AND METHODS}

\section{Evaluation Basis}

All patients included in this study $(\mathrm{n}=598)$ were referred to the Departments of Oral Pathology and of Oral Medicine, Islamic Azad University, School of Dentistry, Tehran, Iran during 12 successive months (Sept 2001-Sept 2002). The basis for referral to the clinic was caries, periodontitis, toothache, prosthetic problems and other complaints such as patients requesting extraction, root planning and scaling or a general dental check-up.

\section{Questionnaire and Examination}

A questionnaire was completed for each patient. In this questionnaire we asked about personal data (age, gender) educational level (basic education, high school or university), occupation (house wife, student, white collar worker, blue collar worker, retired person and others [such as unemployed people or people with no permanent job]), reasons for visiting the clinic (see above: the basis for referral) and smoking habits. Furthermore, the patients were asked about their general health and diseases such as bronchial asthma, bacterial endocarditis, coronary disease, diabetes mellitus, 
drug hypersensitivity, epilepsy, gastrointestinal disease, hepatitis, high blood pressure, hematological disease, infectious disease, kidney disorders, psychological disorders, rheumatic fever and thyroid disease. We also asked about possible addictions (heavy smoking) and medical therapies like blood transfusion, chemotherapy, radiotherapy and medication history. One of us (JJ) examined all the 598 patients using dental unit light and dental mirrors.

\section{Investigational Set-Up}

The tongue lesions fissured-, geographic- and hairy tongue as well as median rhomboid glossitis and lingual varices and the mucosal lesions leukoedema and Fordyce granules were identified and further investigated. The prevalence of these lesions was studied in relation to age, gender, occupation, level of education, and smoking habits as well as the general diseases and disorders mentioned above. The patients of the study gave a written statement of informed consent to participate in the study.

\section{Statistical Analysis}

When comparing lesion prevalence in two patient groups, a two sided exact Fisher test was used. A chi-squares test was used to analyze the association between a lesion prevalence and age, as well as the association between a lesion prevalence and level of education. In order to check whether a prevalence difference between two patients groups could be explained by differences in age, a logistic regression analysis was used, with lesion (yes/no) as dependent variable, and age and the grouping variable as independent variables. A significance level of $5 \%$ was used throughout.

\section{RESULTS}

\section{Patients}

The age distribution is shown in Table 1. Other patient characteristics are shown in Tables $\mathbf{2}$ and $\mathbf{3}$.

Table 1. Age Distribution of Patients

\begin{tabular}{|c|c|c|}
\hline Age & No $(\%)$ & Mean Age \\
\hline \hline-19 & $66(11,0)$ & 16 \\
\hline $20-29$ & $165(27,6)$ & 24 \\
\hline $30-39$ & $123(20,6)$ & 34 \\
\hline $40-49$ & $97(16,2)$ & 44 \\
\hline $50-59$ & $73(12,2)$ & 53 \\
\hline $60-$ & $74(12,4)$ & 65 \\
\hline Total & $598(100)$ & 38 \\
\hline
\end{tabular}

\section{All Lesions}

The oral mucosa lesions were seen in 295 patients $(49.3 \%)$. The prevalence of patients demonstrating lesions increased with age, from $25,8 \%$ in the youngest age group to $74,3 \%$ in the oldest $(p<0,0001)$ (Table 2$)$. The lesions occurred more frequently in men $(62,4 \%)$ than in women
$(37.6 \%)(\mathrm{p}<0,004)$ (Table 2) and the prevalence was strongly related to age. This relation was stronger in men than in women (Table 2). Educational level had little impact on the prevalence of these changes (Table 3 ), in contrast to the occupation of the person where the lowest prevalence of lesions was seen in students $(25,3 \%)$ and the highest in retired persons $(74,4 \%)$ (Table 3). However, after adjustment

Table 2. Oral Lesions According to Age and Gender

\begin{tabular}{|c|c|c|c|}
\hline \multirow{2}{*}{ Age } & \multirow{2}{*}{ Any Lesion } & \multicolumn{2}{|c|}{ Gender Distribution (\%) } \\
\cline { 2 - 4 } & $\mathbf{n}(\%)$ & Men & Women \\
\hline \hline-19 & $17(25,8)$ & 19,2 & 30,0 \\
\hline $20-29$ & $57(34,5)$ & 45,0 & 24,7 \\
\hline $30-39$ & $66(53,7)$ & 65,4 & 45,1 \\
\hline $40-49$ & $53(54,6)$ & 70,5 & 41,5 \\
\hline $50-59$ & $47(64,4)$ & 81,6 & 45,7 \\
\hline $60-$ & $55(74,3)$ & 87,2 & 51,9 \\
\hline Total & $295(49,3)$ & $62,4 *$ & $37,6^{*}$ \\
\hline
\end{tabular}

$*=\mathrm{p}=0,004$.

Table 3. Oral Mucosal Lesions According to Education, Occupation and Chief Complaint

\begin{tabular}{|c|c|c|}
\hline Education & $\begin{array}{l}\text { All Patients } \\
\text { n }\end{array}$ & $\begin{array}{l}\text { Patients with Oral } \\
\text { Lesions n (\%) }\end{array}$ \\
\hline Basic education & 334 & $173(51,8)$ \\
\hline High school & 150 & $68(45,3)$ \\
\hline University & 113 & $53(47,3)$ \\
\hline Total & 598 & $295(49,4)$ \\
\hline Occupation & $\mathrm{n}$ & $\mathrm{n}(\%)$ \\
\hline House wives & 212 & $88(41,5)$ \\
\hline Students & 95 & $24(25,3)$ \\
\hline White collar workers & 95 & $58(61,1)$ \\
\hline Blue collar workers & 74 & $50(67,6)$ \\
\hline Retired people & 39 & $29(74,4)$ \\
\hline Others & 83 & $46(55,4)$ \\
\hline Total & 598 & $295(49,4)$ \\
\hline Chief complaint & $\mathrm{n}$ & $\mathrm{n}(\%)$ \\
\hline Toothache & 144 & $61(42,4)$ \\
\hline Caries & 174 & $68(39,1)$ \\
\hline Prosthesis & 156 & $105(67,3)$ \\
\hline Others & 124 & $61(49,6)$ \\
\hline Total & 598 & $295(49,4)$ \\
\hline
\end{tabular}


for age the difference between occupation groups was no longer significant. Of all patients investigated $17,8 \%$ were smokers, $4,8 \%$ of all women smoked and $31,4 \%$ of all men. Hence, the association between the prevalence of lesions and smoking was mainly studied in men. No significant difference was found between non-smoking and smoking men $(58,5 / 68.5 \%)$ regarding the presence of oral mucosa changes in general (results not shown).

\section{Oral Mucosal Lesions and General Diseases and Disor- ders}

Regarding the general diseases recorded we decided to analyze only those containing more than ten patients. These suffered from hypertension (27 patients, 4,5\%), coronary heart disease (22 patients, 3,7\%), diabetes mellitus (13 patients, $2,2 \%$ ), drug hypersensitivity (48 patients, $8,0 \%$ ), gastrointestinal disease (11 patients, 1,8\%), hematological disorders (12 patients, 2,0\%), kidney disease (28 patients, $4,7 \%$ ), psychological disorders (18 patients, 3,0\%) and thyroid disease (27 patients, 4,5\%) whereas 130 patients $(21,7 \%)$ had a medication history. When all oral lesions were related to the general diseases only drug hypersensitivity, medication and thyroid disease was found to be significantly associated or almost significantly associated $(\mathrm{p}=0,05,0,06$ and 0,05 ) with the above mentioned diseases, therapies and medication. However, when the three entities were adjusted for gender and age the significance disappeared $(p=0,13$, $\mathrm{p}=0,39$ and $\mathrm{p}=0,39$, respectively).

\section{The Different Oral Lesions}

Due to low numbers of patients we did not further analyze the three oral lesions i. e. median rhomboid glossitis, geographic tongue and lingual varices. In patients with the changes Fordyce granules, leukoedema, hairy tongue and fissured tongue the following analyses were done.

\section{Fissured Tongue (Table 4)}

Men and women demonstrated similar prevalence of fissured tongue, (13,2\% and $12,5 \%$ respectively) (Table 4). Fissured tongue increased from the youngest to the oldest age group $(\mathrm{p}=0,0001)$ (Table 4). After adjusting for age, the parameters education, occupation and complaints upon referral had little influence on the prevalence of patients with

Table 4. The Prevalence of Fissured Tongue

\begin{tabular}{|c|c|c|c|}
\hline Age & $\begin{array}{c}\text { All Patients } \\
\mathbf{n}(\%)\end{array}$ & $\begin{array}{c}\text { Men } \\
\mathbf{n}(\%)\end{array}$ & $\begin{array}{c}\text { Women } \\
\mathbf{n}(\%)\end{array}$ \\
\hline \hline-19 & $2(3,0)$ & $1(3,8)$ & $1(2,5)$ \\
\hline $20-29$ & $11(6,7)$ & $7(8,8)$ & $4(4,7)$ \\
\hline $30-39$ & $21(17,1)$ & $10(19,2)$ & $11(15,5)$ \\
\hline $40-49$ & $18(18,6)$ & $8(18,2)$ & $10(18,9)$ \\
\hline $50-59$ & $10(13,7)$ & $3(7,9)$ & $7(20,0)$ \\
\hline $60-$ & $15(20,3)$ & $9(19,1)$ & $6(22,2)$ \\
\hline Total & $77(12,9)$ & $38(13,2)$ & $39(12,5)$ \\
\hline
\end{tabular}

fissured tongue. Among men no significant difference was seen between smokers and non-smokers (Table 8), but the few women who smoked displayed fissured tongue three times more frequently than those not smoking $(\mathrm{p}<0,03)$. Among patients with a fissured tongue the risk of using some form of medication was doubled $(\mathrm{p}=0,001)$ compared to patients without fissured tongue, even when adjusting for age and gender $(\mathrm{p}=0,008)$. In fact those having fissured tongue had, after adjusting for age and gender, a tendency of having some form of general disease $(p=0,06)$. No consideration was taken whether fissured tongue had smooth-surfaced or normal-appearing papillae.

\section{Fordyce Granules (Table 5)}

Fordyce granules were seen in $27.9 \%$ patients. In the 12 19 years age group 10,6\% demonstrated the lesions and 60 years and older 45,9\% ( $\mathrm{p}<0,0001)$ (Table 5). Men demonstrated more Fordyce granules than women in all age groups (totally $37.3 \%$ versus 19,3\%, p<0,0001) (Table 5). After adjusting for age, the parameters education, occupation and complaints upon referral had little influence on the prevalence of Fordyce granules. Among smoking men there were significantly fewer patients with the lesion (26.7\%) than among non-smokers $(42,0 \%),(p=0,02)$ (Table 8 ).

Table 5. The Prevalence of Fordyce Granules

\begin{tabular}{|c|c|c|c|}
\hline Age & $\begin{array}{c}\text { All Patients } \\
\mathbf{n}(\boldsymbol{\%})\end{array}$ & $\begin{array}{c}\text { Men } \\
\mathbf{n}(\%)\end{array}$ & $\begin{array}{c}\text { Women } \\
\mathbf{n}(\%)\end{array}$ \\
\hline \hline-19 & $7(10,6)$ & $26(7,7)$ & $40(12,5)$ \\
\hline $20-29$ & $27(16,4)$ & $80(20,0)$ & $85(12,9)$ \\
\hline $30-39$ & $36(29,3)$ & $20(38,5)$ & $16(22,5)$ \\
\hline $40-49$ & $29(29,9)$ & $18(40,9)$ & $11(20,8)$ \\
\hline $50-59$ & $34(46,6)$ & $24(63,2)$ & $10(28,6)$ \\
\hline $60-$ & $34(45,9)$ & $27(57,4)$ & $7(25,9)$ \\
\hline Total & $167(27,9)$ & $107(37,3 *)$ & $60(19,3 *)$ \\
\hline
\end{tabular}

$*=p<0,0001$

Hypertension was seen in a higher proportion of patients demonstrating Fordyce granules $(\mathrm{p}=0,03$; adjusted for age and gender $\mathrm{p}=0,08)$. Persons having Fordyce granules less often suffered a drug hypersensitivity $(p=0,004)$, even after adjusted for gender and age $(\mathrm{p}=0,015)$. Fordyce granules did not show any significant association with the other diseases tested in this study, nor with medication history.

\section{Hairy Tongue (Table 6)}

Among men, 13,2\% had hairy tongue while in women the prevalence was $4,8 \%(\mathrm{p}<0,0001)$ (Table 6). Among men the prevalence increased from $7,5 \%$ in the age group 20-29 to $19,1 \%$ in the oldest age group, $(\mathrm{p}<0,0001)$ (Table 6). After adjusting for age, the parameters education, occupation and complaints upon referral had little influence on the prevalence of patients with hairy tongue. Among smoking men $23,3 \%$ had hairy tongue as compared to non-smokers with only 8,3\% ( $\mathrm{p}<0,001)$ (Table 8). Among patients with leuko- 
edema $17,3 \%$ had hairy tongue as opposed to $7.6 \%$ among patients without leukoedema $(\mathrm{p}=0,014)$. Hairy tongue did not show any significant association with the general diseases registered in this study, nor with medication history.

Table 6. The Prevalence of Hairy Tongue

\begin{tabular}{|c|c|c|c|}
\hline Age & $\begin{array}{c}\text { All Patients } \\
\mathbf{n}(\%)\end{array}$ & $\begin{array}{c}\text { Men } \\
\mathbf{n}(\boldsymbol{\%})\end{array}$ & $\begin{array}{c}\text { Women } \\
\mathbf{n}(\%)\end{array}$ \\
\hline \hline-19 & $1(1,5)$ & $0(0)$ & $1(2,5)$ \\
\hline $20-29$ & $10(6,1)$ & $6(7,5)$ & $4(4,7)$ \\
\hline $30-39$ & $12(9,8)$ & $7(13,5)$ & $5(7,0)$ \\
\hline $40-49$ & $9(9,3)$ & $8(18,2)$ & $1(1,9)$ \\
\hline $50-59$ & $11(15,1)$ & $8(21,1)$ & $3(8,6)$ \\
\hline $60-$ & $10(13,5)$ & $9(19,1)$ & $1(3,7)$ \\
\hline Total & $53(8,9)$ & $38(13,2 *)$ & $15(4,8 *)$ \\
\hline
\end{tabular}

$*=\mathrm{p}<0,0001$.

\section{Leukoedema (Table 7)}

Men had almost four times higher prevalence of leukoedema $(20,2 \%)$ than had women $(5,5 \%)(\mathrm{p}<0,0001)$ (Table 7$)$. In patients under 20 years of age the prevalence was only $6,1 \%$ while in those over 60 it was $23,0 \%$ ( $p<0,0001$ ) (Table 7). After adjusting for age, the parameters education, occupation and complaints upon referral had little or no influence on the prevalence of leukoedema. Smoking men displayed a relatively high prevalence of leukoedema $(33,3 \%)$ compared to non-smokers $(14,5 \%)(\mathrm{p}<0,0001)$ (Table 8). Leukoedema was seen significantly more often in patients with diabetes mellitus also when adjusted for age and gender $(\mathrm{p}=0,04)$. In the oldest age group (60 and over) with diabetes mellitus leukoedema was found in 4 out of 5 patients as compared to those having diabetes mellitus but no leukoedema $(p=0,009)$. This indicates that elderly leukoedema patients have a tenfold higher risk of having diabetes mellitus. Among patients over 60 years of age $7 \%$ had diabetes mellitus. Of those with leukoedema $24 \%$ had diabetes mellitus. In patients without leukoedema $2 \%$ had the diabetic disease. A tendency for an association between drug hypersensitivity and leukoedema was observed $(\mathrm{p}=0,07)$. Of the 75 patients having leukoedema none had thyroid disease. The prevalence of patients with leukoedema was similar in patients with or without medication.
Table 7. The Prevalence of Leukoedema

\begin{tabular}{|c|c|c|c|}
\hline Age & $\begin{array}{c}\text { All Patients } \\
\mathbf{n}(\%)\end{array}$ & $\begin{array}{c}\text { Men } \\
\mathbf{n}(\%)\end{array}$ & $\begin{array}{c}\text { Women } \\
\mathbf{n}(\%)\end{array}$ \\
\hline \hline-19 & $4(6,1)$ & $2(7,7)$ & $2(5,0)$ \\
\hline $20-29$ & $16(9,7)$ & $13(16,3)$ & $3(3,5)$ \\
\hline $30-39$ & $13(10,6)$ & $7(13,5)$ & $6(8,5)$ \\
\hline $40-49$ & $12(12,4)$ & $11(25,0)$ & $1(1,9)$ \\
\hline $50-59$ & $13(17,8)$ & $12(31,6)$ & $1(2,9)$ \\
\hline $60-$ & $17(23,0)$ & $13(27,7)$ & $4(14,8)$ \\
\hline Total & $75(12,5)$ & $58(20,2 *)$ & $17(5,5 *)$ \\
\hline
\end{tabular}

$*=\mathrm{p}<0,0001$.

\section{DISCUSSION}

This study was made on patients randomly referred to the dental school of Islamic Azad University, Tehran. These patients do not represent any set population. However, the number of patients in the different age groups demonstrate that these lesions are more common among elderly patients as well as among men. We also found likely connections between the oral lesions clinically investigated and some general diseases.

Fordyce granules are ectopic sebaceous glands in the oral mucosa, usually found in the buccal mucosa but also quite frequently in the retromolar area and in the lips [14]. Large variations in the prevalence of the lesion have been reported, from $8 \%$ to $95 \%[14,15]$. Men had Fordyce granules twice as prevalent as women in our study. Fordyce granules may be a target of the androgenic hormones [16]. Men have a higher prevalence of androgen receptors in dermal sebaceous glands but also Fordyce granules than women [16]. We also found that smoking men to a lesser extent had Fordyce granules. This may be explained by the resulting increased thickness of the keratinized layer of the epithelium due to smoke obscuring the pale sebaceous tissue.

As others, we experienced that the prevalence of fissured tongue increased with age $[17,18]$. The lesion in men and women displayed equal prevalence, also reported by others $[17,19]$. Others again have found the tongue lesion more prevalent in men $[18,20]$ even up to the point of $3 / 1$ (men/women) [20]. Fissured tongue has been associated with some general pathological conditions [21-23]. There is a strong evidence for transmission through inheritance [24] in

Table 8. Relationship between Smoking and Four Oral Lesions

\begin{tabular}{|c|c|c|c|c|}
\hline Non-smoking & 42,0 & 11,9 & 14,5 & 8,3 \\
\hline p-values & 0,017 & Non-significant & $<0,0001$ & $<0,001$ \\
\hline
\end{tabular}


fissured tongue which has also has been demonstrated in the Melkersson-Rosenthal's syndrome [25]. A gene linkage between geographic- and fissured tongue has been suggested [26-29]. In children with Downs syndrome $28 \%$ had a fissured tongue [30]. The ten groups of systemic diseases that were investigated in this study demonstrated little association with all of these oral lesions. However, we did find that patients having fissured tongue had an increased tendency of suffering from any of the general diseases $(p=0,06)$.

The etiology of hairy tongue (including black hairy tongue) is unknown but may indicate treatment with topical or systemic antibiotics, poor oral hygiene, heavy smoking and alcohol intake as well as the use of mouthwashes, e. g. hydrogen peroxide $[31,32]$. In line with our study, there was a significant increase from the age groups 20-29 to over 50 [20], while a peak of prevalence at 35-44 have been reported [2]. Men demonstrated a higher prevalence than women, found in our as well as in other studies $[26,20]$. The condition indicates either a defective desquamation of the cells in the central column of filiform papillae and in the formation of highly elongated cornified spines or hairs, alternatively that the rate of formation of keratinized material may be increased [31, 33].

Leukoedema is a chronic condition usually seen in the buccal mucosa. It has a grey and opaque appearance as a film or a veil [34]. Several investigators, including ourselves, have found that smoking increases the prevalence of oral lesions, especially leukoedema and hairy tongue $[5,11,12$, $26,45]$. We found that smoking men displayed leukoedema two times as frequent compared to non-smokers. It has been suggested that the pathogenesis of leukoedema is multifactorial [13], and smoking is one of predisposing factors or even the major cause. Histochemical stains and RNA extraction studies showed that these structures are probably abnormal forms of keratohyalin granules and that ribosomes are an important component of their composition $[35,36]$. Keratohyalin granules are also seen in white sponge nevus and tonofilaments within the epithelial cells [37] having mutations in keratin 4 and 13 [38]. These observations may suggest a link between these lesions. We found that leukoedema could indicate diabetes mellitus in older persons with a tenfold increased risk compared to those not having leukoedema. As the number of patients in our material is rather small this difference must be interpreted with caution. However, this finding suggests that the diagnostic value of leukoedema in elderly patients should be investigated. Diabetic patients have earlier been reported with an increased incidence of fissured tongue [23], which we did not see in our study $(\mathrm{p}=0,23)$.

As in all studies concerning clinical investigations of referred populations one may ask why some of the prevalence figures differ considerably between different geographic areas. Different explanations should be considered: 1.There is real differences in the prevalence of the lesions, 2. Referred groups of patients are not comparable, 3. Specific cultural habits may influence the presence of the lesions, and/or 4. The clinical interpretations of the parameters may vary for diagnosing the lesions. With increased communication and contacts large variations in clinical diagnosis of oral mucosal lesions should be decreasing.

\section{ACKNOWLEDGEMENTS}

We would like to acknowledge the important work of Dr. Rezaee, Head of the Department of Oral Medicine, Islamic Azad University of Tehran, Iran for arranging the examinations of the patients. We would also like to acknowledge the help of professor Stina Syrjänen for reviewing the manuscript.

\section{REFERENCES}

[1] Shafer WG, Hine MK, Levy BM. A textbook of oral pathology, $4^{\text {th }}$ ed. Philadelphia, WB Saunders Co, First chapter, 1983.

[2] Reichart PA. Oral mucosal lesions in a representative crosssectional study of aging Germans. Commun Dent Oral Epidemiol 2000; 28: 390-8.

[3] Martin JL. Leukoedema: an epidemiological study in white and African Americans. J Tenn Dent Assoc 1997; 77: 18-21.

[4] Kullaa-Mikkonen A. Familial study of fissured tongue. Scand J Dent Res 1988; 96: 366-75.

[5] Axell T, Henricsson V. Leukoedema - an epidemiologic study with special reference to the influence of tobacco habits. Commun Dent Oral Epidemiol 1981; 9: 142-6.

[6] Assimakopoulos D, Patrikakos G, Fotika C, Elisaf M. Benign migratory glossitis or geographic tongue: an enigmatic oral lesion. Am J Med 2002; 113: 751-5.

[7] Femiano F. Geographic tongue (migrant glossitis) and psoriasis Minerva Stomatol 2001; 50: 213-7.

[8] Voros-Balog T, Dombi C, Vincze N, Baniczy J. Epidemiologic survey of tongue lesions and analysis of the etiologic factors involved. Fogorv Sz 1999; 92: 157-63.

[9] Beveridge BR, Bannerman RM, Evanson JM, Witts LJ. Hypochromic anaemia. A retrospective study and follow-up of 378 patients. Q J Med 1965; 34: 145-61.

[10] Andersson G, Vala EK, Curvall M. The influence of cigarette consumption and smoking machine yields of tar and nicotine on the nicotine uptake and oral mucosal lesions in smokers. J Oral Pathol Med 1997; 26: 117-23.

[11] Zain RB, Razak IA. Association between cigarette smoking and prevalence of oral mucosal lesions among Malaysian army personnel. Commun Dent Oral Epidemiol 1989; 17: 148-9.

[12] Reichart PA, Mohr U, Srisuwan S, Geerlings H, Theetranont C, Kangwanpong T. Precancerous and other oral mucosal lesions related to chewing, smoking and drinking habits in Thailand. Community Dent Oral Epidemiol 1987; 15: 152-60.

[13] van Wyk CW. An investigation into the association between leukoedema and smoking. J Oral Pathol 1985; 14: 491-9.

[14] Gorsky M, Buchner A, Fundoianu-Dayan D, Cohen C. Fordyce's granules in the oral mucosa of adult Israeli Jews. Commun Dent Oral Epidemiol 1986; 14: 231-2.

[15] Cadugo MA, Chua MG, Feliciano MA, Jimenez FC Jr., Uy HG. A preliminary clinical study on the oral lesions among the Dumagats. J Philipp Dent Assoc 1998; 50: 36-42.

[16] Whitaker SB, Vigneswaran N, Singh BB. Androgen receptor status of the oral sebaceous glands. Am J Dermatopathol 1997; 19: 415-8.

[17] Sedano HO, Carreon Freyre I, Garza de la Garza ML, et al. Clinical orodental abnormalities in Mexican children. Oral Surg Oral Med Oral Pathol 1989; 68: 300-11.

[18] Kullaa-Mikkonen A, Mikkonen M, Kotilainen R. Prevalence of different morphologic forms of the human tongue in young Finns. Oral Surg Oral Med Oral Pathol 1982; 53: 152-6.

[19] Farman AG. Tongue fissures. A classification and comparative prevalence study among 825 European Caucasian and 605 Xhosa Negro school children. J Biol Buccale 1976; 4: 349-64.

[20] Avcu N, Kanli A. The prevalence of tongue lesions in 5150 Turkish dental outpatients. Oral Dis 2003; 9: 188-95.

[21] Vistnes LM, Kernahan DA. The Melkersson-Rosenthal syndrome. Plast Reconstr Surg 1971; 48: 126-32.

[22] Bessa CFN, Santos PJB, Aguiar MCF, do Carmo MAV. Prevalence of oral mucosal alterations in children 0 to 12 years old. J Oral Pathol Med 2004; 33: 17-22.

[23] Guggenheimer J, Moore PA, Rossie K, et al. Orchard T. Insulindependent diabetes mellitus and oral soft tissue pathologies. I. Prevalence and characteristics of non-candidal lesions. Oral Surg Oral Med Oral Pathol Oral Radiol Endod 2000; 89: 563-9. 
[24] Rahaminmoff P, Muhsam HV. Some observations on 1246 cases of geographic tongue: the association between geographic tongue, seborrheic dermatitis, and spasmodic bronchitis; transition of geographic tongue to fissured tongue. AMA J Dis Child 1957; 93: 51925.

[25] Smeets E, Fryns JP, Van den Berghe H. Melkersson-Rosenthal syndrome and de novo autosomal t(9;21)(p11;p11) translocation. Clin Genet 1994; 45: 323-4.

[26] Darwazeh AM, Pillai K. Prevalence of tongue lesions in 1013 Jordanian dental outpatients. Commun Dent Oral Epidemiol 1993; 21: 323-4.

[27] Ghose LJ, Baghdady VS. Prevalence of geographic and plicated tongue in 6090 Iraqi schoolchildren. Commun Dent Oral Epidemiol 1982; 10: 214-6.

[28] Chosack A, Zadik D, Eidelman E. Prevalence of scrotal tongue and geographic tongue in 70,359 Israeli school-children. Commun Dent Oral Epidermiol 1974; 2: 253-7.

[29] Redman RS. Prevalence of geographic tongue, fissured tongue, median rhomboid glossitis, and hairy tongue among 3,611 Minnesota schoolchildren. Oral Surg 1970; 30: 390-5.

[30] Daneshpazhooh M, Nazemi TMJ, Bigdeloo L, Yoosefi M. Mucocutaneous findings in 100 children with Downs syndrome. Pediatric Dermatol 2007; 24: 317-20.
[31] Pindborg JJ. Atlas of diseases of the oral mucosa. $5^{\text {th }}$ ed. Munksgaard Copenhagen, 1992.

[32] Langtry JA, Carr MM, Steele MC, Ive FA. Topical tretinoin: a new treatment for black hairy tongue (lingua villosa nigra). Clin Exp Dermatol 1992; 17: 163-4.

[33] Manabe M, Lim L, Winzer M, Loomis C. Architectural organization of filiform papillæ in normal and black hairy tongue epithelium. Dissection of differentiation pathways in a complex human epithelium according to their patterns of keratin expression. Arch Dermatol 1999; 135: 177-81.

[34] Salonen L, Axell T, Hellden L. Occurrence of oral mucosal lesions, the influence of tobacco habits and an estimate of treatment time in an adult Swedish population. J Oral Pathol Med 1990; 19: 170-6.

[35] van Wyk CW, Ambrosio SC. Leukoedema: ultrastructural and histochemical observations. J Oral Pathol 1983; 12: 319-29.

[36] van Wyk CW, Ambrosio SC, van der Vyver PC. Abnormal keratohyalin-like forms in leukoedema. J Oral Pathol 1984; 13: 271-81.

[37] McGinnis JP Jr., Turner JF. Ultrastructure of the white sponge nevus. Oral Surg Oral Med Oral Pathol 1975; 40: 644-51.

[38] Terrinoni A, Candi E. Oddi S, et al. A glutamine insertion in the $1 \mathrm{~A}$ alpha helical domain of the keratin 4 gene in a familial case of white sponge nevus. J Invest Dermatol 2000; 114: 388-91.

(C) Jahanbani et al.; Licensee Bentham Open.

This is an open access article licensed under the terms of the Creative Commons Attribution Non-Commercial License (http://creativecommons.org/licenses/ by-nc/3.0/) which permits unrestricted, non-commercial use, distribution and reproduction in any medium, provided the work is properly cited. 